\title{
Reader's Empire: The Reader Is the Main Focus in Receptor Theory (Receiving Beauty) and Communication Code with Literature Text
}

\author{
Abeer Obeid Irhail Al Shbiel \\ Arabic language Department, Irbid University college, Al Balqa' Applied University, Jordan
}

\begin{abstract}
The Receptor theory receiving beauty is considered today one if the most important theories in term of literature quality, so. The reader is the one who determines the dimension of that quality through the influence of literature image on him in fact the literature work is effect and influence, and communication, so, if it's influence is large on its receiver, and it's receiver communicated with it, so it achieved it's literatarity, and gave the text a high value, and gave them the opportunities of survive through ages, so, the survival of literature works is a survival of its receiver self. The results of this study indicated that the effectiveness of reading, receiving and communicating is very important, because it has an authority on the text and give the reader the larger role in the process of receiving, reading, or communication with the text, if there is no food reader to per produce the literature work. From here, I tried to focus on this reader through his simple and complex types and the effect of that on the text and its producer. So, it was clear that this reader has a role before and after producing the literature work.
\end{abstract}

Index Terms—reader, receiving and reading theory, communication with text, modern Arabic critique

\section{INTRODUCTION}

The Receptor theory (Astatiqa= receiving beauty) is considered today one if the most important theories in term of literature quality, so. The reader is the one who determines the dimension of that quality through the influence of literature image on him in fact the literature work is effect and influence, and communication, so, if it's influence is large on its receiver, and it's receiver communicated with it, so it achieved it's literatarity, and gave the text a high value, and gave them the opportunities of survive through ages, so, the survival of literature works is a survival of its receiver self.

This theory, and what is it combined with looking after reader or receiver and text, came in civilization context which is the reasoning climate in western, so it was an increased feeling with separating between literature and its audience, and poetry- in particular-so, there was agape which separates the reader from the text, and doesn't care with the communication code between it and the text creator, and a lonely climate is formed between the three creative work basis which are: the creator, the text, and the reader. That led some critiques and researcher to study his phenomenon, because the recognized that the beauty subject can't be achieved and integrated without receiving and communication, so receiving puts it in self and transforms it into effected internal image, also, because the perfect performance doesn't measured or determined based on performance alone, but it requires referring to those who recognize the conducted article produce that means, if the work is wonted to be in meaningful article, it must be with beauties (alwad,1994).

The theory of receiving (reading) was developed in the framework of analytical philosophy which looks to the reading process from the corner of reader's sense of it (Khawaja, 1994), which considered it as the base of achieving the literature text, because literature work is not fund until it achieved by the reader, in that, reading $g$ will be the new form of the text.

After this brief introduction to the receptor theory we have to mention that contestants Germany University has an important role in revealing this theory by (H.R .yaws) and (F. Izar) and their modern hypothesis, dissertations.

\section{The Process of Communicating Reading And the Reader}

It may be said that the base of receptor theory Is revealing the role of reader and his effectiveness in interpreting literature works and contributing in reevaluating them and giving them a meaning according, to asset of factors related to the nature and his time and culture, so, the placement of reader- receiver- gains an increased importance and still one of the primary issues in this theory. That means that the studied focused on revealing the relations of effect and in flounce in the works under comparative study started to francs form Germany theorists and their fellows of this theory in to the last party of the equality which includes (the author, the reader). After the attention transformed from author in to text, the reader became having an authority in directing the text and determining its value. While each text is directed to the reader, so apart of critique will include recovering its implicit or practical reader (Ibrahim, 1990). However, the science of interpretation developed by some Gorman theorists of receptor theory tends to focus on past work and cues 
through reviewing and reading them that the major role for critique is understanding these works by under- standing the direct or indirect effect (Ayyad, 2002).

We notice that the reader (receiver) is the major focus in receiving process, these, this study will start from this focus to show the process of communicating reading and the reader ( receiver), and his types, reading types, and How reading process conducted, and levels, and the problem of communicating reading $g$ effectiveness and reader receiving $g$, then the research conclusion.

\section{A. The Reading Process and Reader}

Reading is considered a process of access the context and communication with it, which an attempt to categorize the text in a context which includes it with similar ones, and this text is not found except in its context (and the text doesn't hold its meaning and value as a stable, but it's an existence the reader gives to the text, and according to what is this gift the existence is being (Howaidi, 1999). The reader starts (to raise questions for which he looks for answer in the text, these questions may be implicit or explicit, but it's important to determine the mechanisms of reading according to the nature of the reader who raises questions, so, each reader looks at the text from his own corner which imposed the nature of the raised questions, because each text has two sides, an objective side refers to language, which makes understanding process possible. And self side refers to author reasoning, and it's cleared in its special use to language (Kudhair, 1999). Both sides refer to the author experience which the reader tend to rebuild it, and the reader has the right from any side he wants according to the nature of his raised questions.

This process is not pure beauty enjoyment focuses on the form, but it's an existence participation process based an argument between the receiver and the work, and it is based, in addition to the reader questions, on the base of the question raised from the work itself, so both experiences mixed in new product based on knowledge an d enjoyment of work to the reader, so, reading $\mathrm{g}$ is considered writing in another way for bath work in one work which is the enjoyment (Al- Ghuthami, 1995).

The literature work take in its way to the receiver (two ways aiming two different styles from literature receivers and who deal with it, the first way tends to the audience which doesn't refer to general case of receiving, and to general space of psychological, that, and knowledge, depends in receiving literature on shared motives don't give space to personal gaps it receives the literature effect in group, and sharing in advertising the poem festival (Al- Maqaleh, 1981).

The second way represented by readers who were not shared, they were isolated sample, or embodying the receiving individuality and personality, and when they touch the poem (each of them depends on his body and soul isolation to direct it towards him)" in his own method, from here, the variety of items came (Estaif, 1997).

This reader represented in the second style, his receiving doesn't aim at responding freely to the text to meet his beauty need, and in his funny isolation desired to possible personal receiving in its individuality, but the reader became new aggressive his response to the text forms the whole body of critique ( Al- Allaq,1998). From here the critique direction based on the reader authority, based on his response to the creative text originates. The text is not an achievement to his anther, but it became a product by the reader this focus on the reading effective made the reader activity originates a large number of meanings, each reader to the text embodies one of possible meaning to the readable text, after the text was limited to one meaning related to the anther meaning.

\section{B. The Types of Reading and Readers}

The meaning of reader here is a reader of special kind, who is trained know, doing efforts, free, based on back ground, and not a negative creator who receives texts and accepts them and responds to them without recognizing their meanings, he is in front of a world of reasoning freedom in understanding the text (so, receiving is reasoning, that is, no one reading to the text when the reader made an effort), (Mubarak,1999) the reader meeting with the text forms the real literature existence to the text, because the text is closed existence, and isn't achieved without the reader who practice reading process divides it into three types (Ayyashi,1992).

A: scanning reading: it's a traditional type of reading and doesn't focus on the text, but it pass from it towards the author or the population, and the role of reader in this type is very limited.

B: explaining reading: this reading obligates with explaining, but it take the external meeting, and five this meaning a preventing above words, so, the text explaining explains alterative words for the same meanings, and this is also limit the reader position.

$\mathrm{C}$ : the poetic reading: which is reading the text through the poetic of its context design, this tends to reveal the internal text, and reads what is farther of its current pronunciation, that makes it with more ability to explain the facts of literature experience and enrich the language.

In this last type the role of reading is appeared in which it interacts with writing elements represented in good tricks which put the reader in the problems of his human life as the first creator and reader of the text evidence (Abu Zaid,1992) .from have this reader must take more importance in all production process stages, that leads to rebalance of literature process itself by returning the rights of this reader which cause the deeper understanding to the text so the integration between the article point which is the anther text and the beauty point which is the achievement of the text which came from the reader response is returned.

This reader came in many types (Awadh, 1994):

A: a receiver who is absolute from time and place. 
B: The actual receiver who really receives the text in simple and limited conditions with the possibility of being normal receiver who don't have except the lowest limits of experience, also, he may be with high level with knowledge procedures, and that makes his receiving a complex, between the not according to his experience and knowledge.

$\mathrm{C}$ : The implicit receiver chosen by the anther when he produce his text, and this proposed receiving by the producer is un actual receiver inspire of his relation to the writer awareness because of his vast experience.

D: The optimal receiver, who is wanted by each producer, is able to unite with the work in each step of producing literature text, and after that, he behaves as the producer wants, and shows what he wants of facts objectives, and purposes, and make use text as the producer planned.

E: The receiver writer who takes the role of text receiver after producing it, and tries to text it.

The producer of literature text is considered the first receiver to his text, because he has knowledge and awareness with related to divide the beauty task of literature work (Fidel Ealah,1999) This receiver participates actively in producing text, so he engages with all producers' choices that include all sides and level of literature text. From here, the receiver was major in the process of producing creative text, and while and before the process of producing. So, the producer makes choice process when he puts himself in the place of receiver, and tends to look at the text in his eyes, and makes same changes because of the advices and recommendation from the receiver, and other receivers, friends, arbitrators.

After that, the role receiver is touched, who is the actual receiver for the literature text who has the abilities of producer, although his total receiving is not objective, because his actual receiving is opened and unlimited with time, place, language, or country, and this role starts as the literature work is spread, but what benefit's the text here I the reader who can free the text from the authority of interpreting and reading it, and then, leave it to be evidence after the producer was the first master who has the rights of interpreting, selecting and directing, and when he loose his ability, a conversational relation originated between text and reader, so, reading was developed and became cultural creative and achievement by a producer reader differs from the old reader, also, this direction is developed, and the authority of the anther is decreased, and the age of reader who became the interpreters who id like the critique is came the difference between them is that the critique is social Job in looking after the article values, and that cause the critique to be a guard for the literature who able to represent it to be understood, not just as mental understanding, but the spiritual responding with values which are escalated also, he must be able to see the new which reform theatrical values to express on the kite and ideas of the beings.(every serious reader deals with literature works as the critique deal although he doesn't obligate the arbitration). Also, the critique will not be critique until he start to read the text interestingly before thinking in it the critique manner, because this type reading make the reader feel with freedom which let reader reach into the accurate judge by the personal awareness with the beauty value, and the reader doesn't depend on critique just for reaching into this value because he is asked to taste all arts. So, the receiver finds himself unable to understand them, because he is empty culturally, and for from any value system help him to firm a wisdom in literature works. But the receiver, who communicates with text and accepts it, is the reader who makes beauty, whose creativity is more than the originator creativity.

From here, literature has argument relation between text and reader, from their communicating, the literature existence id formed (so, literature is text and reader, the text is ambiguous existence as a dream doesn't achieve without reader). That ensured the importance of reader and the effective of reading as a primary process to the literature existence, so, the modern writer care with reader through his creative process, so he try to direct him by poetry statements and opening some gaps in a poem to enable the capable reader to close it and reproduce the poem (Aja,1991).

The relation between them and the receiver depends on language, and directs into one purpose which is producing the literature meaning in its language and it's the source of evidence which the reader must built, and it's the starting point for all proposed challenges for the article work and it's what open the door behind the written text and it's the opening to produce meaning by looking behind the written text by this text which cause preparing thee literature work the reader is the point of moves vision (Al- Maqaleh,1981).

The reader faced through reading process the communication with literature text codes and it's total context after variable of changed situation between many emotions that cause him to cry or laugh and the reader may avoid these positions because of its design and knowledge ( the world of modern literature has far spaces expanded in front of self, so the vision recognize what appear from it and remember what is absent it's important that the reader be communicated with the text to recognize it.

\section{How the Process of Reader's Reading and Communication Conducted}

The aspects of reader meeting with text are various and start with reading text through put it with in context, then knowing it, then opening it's spaces and communicating with it (an d its components Flourished it to and with alive in the reader for this text. This flourishment doesn't mean the escaping of text from its system, but it means that the reader know the text system, so the tax is flourished at this moment connected with its system and it's language structures and separating from its book, because it doesn't accept nor it's context (Awadh,1994).

\section{RECEIVING}

\section{A. Receiving Levels}


Reader while reading process deals with different receiving levels; it may be still the opinions of another person who is the author because he doesn't want his personality to disappear. That means that the process of reading, receiving, and communicating is a process of mixing between the other and the real self (Author / Reader) and communicating between them, in which the reader is in his full awareness and his achievement is expected and he torch his expectation then modified it that results putting all expectation in their integrated frame work from this reader paint of view which forms of literature work reading. This level is called the Top of expectation which the extent of vision for everything in suitable site.

Through the process of reading $g$ of reading and communicating and with in expectation, the reader tries to show his experience also, he tries to originates a shared area between this special experience and the experience of writer in his embodied image. This level called beauty distances, which means the changing of expectation by the various reading. In this, the reader can observe himself and the other in the same time. The reading process it's done without perceptual spiritual engagement by the reader, this level called the space integration (Fidel Ealah, 1999).

\section{B. The Problems of the Effective Communicating Reading and Readers Receiving}

Reading effectiveness is considered important because it related to text, but that bring more problem because of readers communicating $\mathrm{g}$ with text, this role may be done by incompetent readers. Ethereal protection to the protection to the text in this domain is the context the complete knowledge of context considered a primary condition for correct reading, any reading can't be considered correct without starting from the context in interpreting text codes and analyzing them, so the self factor is very important in the correct reading g, but it's not absolute to impose unlimited Authority on the text, with the verity reading $g$ to a specific text we find some shared factors link these reading with each other's event, they are different, because there is no correct reading to the text without objective control but they must be controlled by awareness, culture, article ability and context scales, from here, they gain their ability and effect (Aja, 1991).

The problem of communicating between the writer and the receiver is an important one, especially, in poetry that characterizes it with complexity an d ambiguity. The reason of this conflict is the large ignorance in our Arab audience to comprehend the simplest condition of Arts which decreased its ability to comprehension because of ignorance, political and social injustices, the absent of Democratic an d social organizations.

The receiver, however, the easy and low radical works are more accepted by the audience because of the previous reasons. And to other psychological reasons, the audience prefers the easy and fast works, which responses to specific motives, as the current life imposed new type of receiving different from the past conflicts, the article works is complicated and became with higher level because of variety culture, while cultural and social life doesn't develop to be suited with literature works, so literature still near some people just. Because recoat literature product needs a large experience and culture and spent a time of text. Also, the audience dose not interacts with text or responds to it without any relation with his life (Kudhair, 1999).

The reader finds himself in conflict when dealing with some literature types, especially in poetry, because it doesn't depend on employing one code to the sender, then receiving them in union manner, but often, it sends many codes, and that cause misunderstanding in emerging evidence.

Also, the poet may council the signs of objective determining because of modernist, but the receiver finds himself motivated to take one of both situation, according to the degree of his awareness with modern poetry movement, so, this absent of poetry subject many surprised him when he searches about certain, determinant without finding them, without being active to take on other step in recognizing the article alternatives, because he is controlled with his traditional expectation with one code to the experience subject or to recognize this a absent which is considered the major feature for the modernity poetry, an d pass through it in to the real knowledge with the text, so, he is not satisfying after he used to the absence of objective determinant about its appearance clearly, because the role of such reader in such text will be limited the text featured with objectively unlimited is wider For this reader to participate, while the first type of receivers said that the poet is ambiguous. Forgetting hi needs to the understanding which doesn't include the clarity which isn't the result of the objective determining so, he must train on passing the first need of understanding because poetry doesn't stop on understanding because it's elements ire more than the limits of logic, so he is in need to the recognition at the base that recognition consists of sensory, spiritual and mental receiving categories.

Also, the receiver need to take a correct situation of the previous literature traditions so, he doesn't controlled by them negatively, from here, the importance of rehabilitation the reader and training them to understand the high the situ for the text, came (Ayyad, 2002).

\section{CONCLUSION}

At the End, we may say that the effectiveness of reading, receiving and communicating is very important, because it has an authority on the text and give the reader the larger role in the process of receiving, reading, or communication with the text, if there is no food reader to per produce the literature work. From here, I tried to focus on this reader through his simple and complex types and the effect of that on the text and its producer. So, it was clear that this reader has a role before and after producing the literature work. 
This, the reader transformed into evil who controls the text and its producer at the end I tried to investigate some problems faced the literature text, and the reader, because he is unable, and that led some to describe the text with complexity.

\section{REFERENCES}

[1] Ibrahim, Zakariya. (1990). Art philosophy, Arab Cultural center, Beirut.

[2] Abu Zaid. Nasir, Hamid. (1992). Problems of reading and interpreting mechanisms. Arab cultural center. Beirut.

[3] Aja, Duraid. (1991). poetic ambignity in new Arab poem, memory center, V. 1, p. 15.

[4] Al- Allaq, Ali Ja`far. (1998). poetry and receiving, critical study, Al- Shourouq center, V.1, p. 63.

[5] Al- Ghuthami, Abdulla. (1995). error and thinking, from structure to analysis, cultural literature club, Jedda.

[6] Al- Maqaleh Abdel Aziz. (1981). Arab poem conflict, modernity center, Beirut.

[7] Ayyashi, Mundher. (1992). second writing and enjoyment opening, Arab cultural center, Beirut.

[8] Ayyad shukri. (2002). introduction to critique and creative, modern Elyas center, Cairo.

[9] Alwad Hussain. (1994). Al- shabby course under the title the effect of poetry discourse in receiving, p.7.

[10] Awadh, yusef. (1994). Critique theory. Al-Amin center, Cairo.

[11] Estaif, Abdel- nabi. (1997). literature text and receiver, literature situation, Damascus, V.30, p.13.

[12] Fidel Ealah. (999). text codes, an eye for social human studies, cairo, V. 1, p. 9.

[13] Howaidi, saleh. (1999). Modern literature critique. Literature reasoning Journal .Beirut. p. 76.

[14] Khawaja, Duraid. (1994). Poetic ambiguity in new Arab poem, memory center, Hemss, V.I, p.19.

[15] Kudhair, Deia`a. (1999). The placement of receiver in comparative literature, signs in critique sournal, Jedda. V. 34, p.p 102103.

[16] Mubarak, Mohammad. (1999). receiving text among Arab, Arab organization for studes and puplish, v. 1, p. 48.

\footnotetext{
Abeer Obeid Irhail Al Shbiel was born in Jordan -Irbid on Eighth -August -1978. She got her PhD degree in Applied Arabic linguistics from Yarmouk University/ Jordan by 2010.

She is currently occupying an assistant professor position in Department of Arabic Language/Irbid University College/Balqa Applied University/ Jordan.

She published a number of articles such as: Tolerance culture in children literature: a case study on Jordan, Journal of Language and Literature, 2013.
} 